\title{
Evaluating Freeze Tolerance of Bermudagrass in a Controlled Environment
}

\section{Jeffrey A. Anderson ${ }^{1}$, Charles M. Taliaferro ${ }^{2}$, and Dennis L. Martin ${ }^{1}$ Oklahoma State University, Stillwater, OK 74078}

Additional index words. acclimation, cold hardiness, Cynodon dactylon $\times$ C. transvaalensis

Freeze tolerance is an important characteristic in bermudagrass [Cynodon dactylon (L.) Pers. $\times C$. transvaalensis Burt-Davy] bred for the geographic transition zone between warmand cool-season turfgrasses. Field-grown turf has been sampled and exposed to controlled freezing and viability testing to evaluate relative hardiness of cool-season grasses (Gusta et al., 1980), St. Augustinegrass [Stenotaphrum secundatum (Walt.) Kuntze] (Fry et al., 1991), and bermudagrass (Anderson et al., 1988). However, acclimation of field-grown plants is not reproducible and is subject to seasonal constraints. Cold hardening of cool-season grasses has been reported following acclimation in controlled environment chambers at 5 and 0C (Rajashekar et al., 1983). Our objectives were to develop procedures to evaluate freeze tolerance of bermudagrass genotypes acclimated under controlled conditions and to screen large numbers of genotypes for superior freeze tolerance.

Relative hardiness levels. Clonally propagated plants of 'Tifgreen', 'Tifton 10', 'Midfield', 'Vamont', 'Midlawn', and 'Midiron' were grown from sprigs in 0.16liter "cone-tainers" (Ray Leach Cone-miner Nursery, Canby, Ore.) in a greenhouse maintained above $22 \mathrm{C}$ for at least 6 weeks. A medium containing 3 peat : 2 sand : 2 vermiculite (by volume) was amended with fritted trace elements. While growing in the greenhouse, plants were fertilized at each watering with $300 \mathrm{mg}$ 20N-9P-17K soluble fertilizer/ liter (Peters Professional, W.R. Grace \& Co., Fogelsville, Pa.). No fertilizer was applied during acclimation. Plants were transferred from the greenhouse to a controlled-environment chamber (model PGW36; Conviron, Asheville, N.C.) and set at 8/2C day/night

Received for publication 30 Nov. 1992. Accepted for publication 31 Mar. 1993. Oklahoma Agricultural Experiment Station publication no. 6370. We gratefully acknowledge the assistance of Glenn Drown, John Lamle, and Susan Kenna. This study was supported in part by the Oklahoma Agricultural Experiment Station and grants from the U.S. Golf Association and the Oklahoma Center for the Advancement of Science and Technology. The cost of publishing this paper was defrayed in part by the payment of page charges. Under postal regulations, this paper therefore must be hereby marked advertisement solely to indicate this fact.

${ }^{1}$ Dept. of Horticulture and Landscape Architecture. ${ }^{2}$ Dept. of Agronomy. cycles based on preliminary experiments (data not presented). A photosynthetic photon flux of $\approx 300 \mu \mathrm{mol} \cdot \mathrm{m}^{-2} \cdot \mathrm{s}^{-1}$ at canopy height was maintained during the 10 -h photoperiod.

After 4 weeks at $8 / 2 \mathrm{C}$, plants were brought to the laboratory, and soil was watered to field capacity. Top growth was trimmed to $2 \mathrm{~cm}$, and a thermocouple was inserted $2 \mathrm{~cm}$ into the soil in the center of each cone-tainer to monitor temperature with a datalogger. Four subsamples per genotype for each of seven subfreezing temperature treatments were placed in a 2 -cm-thick aluminum plate with holes drilled to accommodate the cone-tainers. Plants wereplaced in a low-temperature freezer (model CEC23; Rheem Scientific, Asheville, NC.) and equilibrated at $-3 \mathrm{C}$. After crushed ice was sprinkled over plants in each conetainer to prevent excessive supercooling, samples were held overnight at $-3 \mathrm{C}$. Chamber temperature was lowered $1 \mathrm{C} / \mathrm{h}$, and plants were removed at $1 \mathrm{C}$ intervals, based on thermocouple measurements. Thermocouple wires contained detachable plugs (Omega Scientific, Stamford, Conn.) to facilitate removal of the cone-tamers, because thermocouple junctions were held firmly by the frozen medium. Cone-tainers were removed from the freezer and held overnight at SC to thaw slowly. Plants were evaluated for regrowth after at least 4 weeks in the greenhouse. Weak shoots that died shortly after emergence were counted as not viable. Temperatures resulting in no regrowth from $50 \%$ of the cone-tainers $\left(\mathrm{LT}_{50}\right)$ were determined by linear interpolation for each repetition of the experiment. The experiment was conducted six times during 1991 and 1992.

Selection. In the first selection experiment, 292 seedlings $(98,96$, and 98 plants on the three dates, respectively) from a geographically isolated cross of plants derived from 'Arizona Common' were screened for superior cold tolerance. Established seedlings were acclimated, then exposed to freezing temperatures as described above, except that all plants were removed at $-8.7 \pm 0.1 \mathrm{C}$ (mean $\pm \mathrm{SD}$ ). We recorded survival and vigor, the latter based on the interval before regrowth was apparent, and a subjective determination of the amount of tissue produced. Four of the most vigorous survivors were clonally propagated and retested withadditional (nonscreened) seedlings from the original crosses to evaluate whether survival was the result of greater freeze toler-
Table 1. Temperatures resulting in 50\% survival $\left(\mathrm{LT}_{50}\right)$ of bermudagrass genotypes exposed to freezing temperatures in cone-tainers in a freezer following 4 weeks acclimation at $8 / 2 \mathrm{C}$ in a controlled-environment chamber. Values are means \pm SE of six determinations.

\begin{tabular}{lc}
\hline \hline Genotype & $\mathrm{LT}_{50}\left({ }^{\circ} \mathrm{C}\right)$ \\
\hline Tifgreen & $-7.7 \pm 0.1 \mathrm{a}^{\mathrm{x}}$ \\
Tifton 10 & $-7.9 \pm 0.3 \mathrm{ab}$ \\
Midfield & $-8.7 \pm 0.3 \mathrm{bc}$ \\
Vamont & $-9.5 \pm 0.1 \mathrm{c}$ \\
Midlawn & $-9.5 \pm 0.3 \mathrm{c}$ \\
Midiron & $-9.6 \pm 0.4 \mathrm{c}$
\end{tabular}

${ }^{\mathrm{z}}$ Mean separation by Duncan's multiple range test, $P$ $\leq 0.05$.

ance or experimental variability. On each of six dates, 124 plants (120 nonselected plus four selected) were evaluated.

Relative hardiness levels. $\mathrm{LT}_{50}$ values ranged from -7.7 to $-9.6 \mathrm{C}$ for six turf-type bermudagrasses (Table 1). Although different combinations of genotypes had been evaluated in other studies (Anderson et al., 1988; Batten et al., 1979; Beard et al., 1980), relative rankings for freeze tolerance were similar to those reported previously.

Selection. Thirty-four out of 292 plants (12\%) survived exposure to $-8.7 \mathrm{C}$ in the first screening experiment. When four survivors were retested, along with additional unscreened plants, all four survived on five of the six repetitions of the experiment and three of four survived the sixth repetition. Survival of the unscreened plants in the second experiment ranged from $9 \%$ to $27 \%$ over the six dates, with a mean of $16 \%$. Although few plants were retested, their consistent survival suggested that they had been selected due to superior freeze tolerance, rather than experimental variability.

Screening bermudagrass genotypes for freeze tolerance following acclimation in controlled-environment chambers appears to have potential for breeding programs. Using conetainers for growing, acclimating, treating, and evaluating plants reduces labor and space requirements and minimizes disturbances to the plants from transplanting.

\section{Literature Cited}

Anderson, J.A., M.P. Kenna, and CM. Taliaferro. 1988. Cold hardiness of 'Midiron' and 'Tifgreen' bermudagrass. HortScience 23:748-750.

Batten, SM., J.B. Beard, and G.M. Pittman. 1979. Bermudagrass cultivar characterization. Texas Agr. Expt. Sta. Prog. Rpt. 3676.

Beard, J.B., S.M. Batten, and G.M. Pittman. 1980. The comparative low temperature hardiness of 19 bermudagrasses. Texas Agr. Expt. Sta. Prog. Rpt. 3835.

Fry, J.D., N.S. Lang, and R.G.P. Clifton. 1991. Freezing resistance and carbohydrate composition of 'Floratam' St. Augustinegrass. HortScience 26:1537-1539.

Gusta, L.V., J.D. Butler, C. Rajashekar, and M.J. Burke. 1980. Freezing resistance of perennial turfgrasses. HortScience 15:494-496.

Rajashekar, C.B., D. Tao, and P.H. Li. 1983. Freezing resistance and cold acclimation in turfgrasses. HortScience 18:91-93. 